\begin{tabular}{|c|l|}
\hline Title & $\begin{array}{l}\text { Synonymy of Cryptopsocus Li with Trichadenotecnum Enderlein (Insecta: Psocodea: 'Psocoptera': Psocidae) and } \\
\text { description of three new species }\end{array}$ \\
\hline Author(s) & Yoshizawa, Kazunori; Lienhard, Charles \\
\hline Citation & $\begin{array}{l}\text { Zootaxa, 3957(4), 480-488 } \\
\text { https://doi.org/10.11646/20otaxa.3957.4.8 }\end{array}$ \\
\hline Issue Date & 2015-05-19 \\
\hline Doc URL & http://hdl.handle.net/2115/59475 \\
\hline Rights(URL) & http://creativecommons.org/icenses/by /3.0/ \\
\hline Type & article \\
\hline File Information & 70122 (yoshizawa) .pdf \\
\hline
\end{tabular}

Instructions for use 
http://dx.doi.org/10.11646/zootaxa.3957.4.8

http://zoobank.org/urn:lsid:zoobank.org:pub:D0CE18B2-353C-4D9B-A28D-9EDD5DD61BA2

\title{
Synonymy of Cryptopsocus Li with Trichadenotecnum Enderlein (Insecta: Psocodea: 'Psocoptera': Psocidae) and description of three new species
}

\author{
KAZUNORI YOSHIZAWA ${ }^{1} \&$ CHARLES LIENHARD ${ }^{2}$

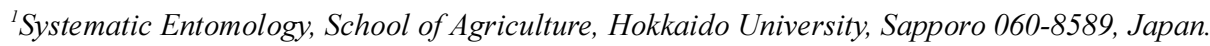 \\ E-mail: psocid@res.agr.hokudai.ac.jp \\ ${ }^{2}$ Muséum d'histoire naturelle, C.P. 6434, CH-1211, Genève 6, Switzerland
}

\begin{abstract}
The genus Cryptopsocus Li, 2002 is synonymized with Trichadenotecnum Enderlein, 1909. The type species of Cryptopsocus, T. cynostigmus (Li, 2002) n. comb., is considered to be a close relative of T. marginatum New \& Thornton, 1976. These species cannot be assigned to any species group previously established in Trichadenotecnum so that the marginatum species group is here proposed for them. Three new species belonging to this species group are described: T. tigrinum and T. sharkeyi from Thailand and T. sabahense from Sabah, Malaysia. The phylogenetic position of the marginatum group is discussed using morphological data.
\end{abstract}

Key words: Psocini, Trichadenotecnini, Ptyctini, new species, Thailand, Sabah

\section{Introduction}

The monotypic genus Cryptopsocus was established by Li (2002) for a single species, C. cynostigmus Li, 2002 , known only from a single male. Its superficial similarity to Trichadenotecnum, a diversified and widely distributed genus, was already pointed out by Li (2002), but he considered these genera as distantly related and classified them in different tribes. He assigned Cryptopsocus to the tribe Psocini and Trichadenotecnum to the Trichadenotecnini (now synonymized with Ptyctini; see Yoshizawa \& Johnson, 2008). However, their differences mentioned by Li (2002) are mostly minute (roof of areola postica straight and forewing with marginal cloud in Trichadenotecnum; roof of areola postica slightly angulated and forewing margin clear in Cryptopsocus). Absence of the clunial lateral processes, the presence of which is a unique feature of Trichadenotecnum, is also pointed out by Li (2002) to differentiate Cryptopsocus from Trichadenotecnum. However, lack of the clunial lateral processes is quite frequent in the basal lineages or even among the more derived members of Trichadenotecnum (Yoshizawa, 2003; Yoshizawa et al., 2008, 2014). Furthermore, Yoshizawa et al. (2014) pointed out that a species of Trichadenotecnum from Malaysia, T. marginatum New \& Thornton, 1976, might be a close relative of Cryptopsocus cynostigmus. Therefore, the delimitation of these genera becomes obscure and it is highly desirable to clarify their phylogenetic relationship and taxonomic status.

Recently, we had the chance to examine specimens from Thailand and Sabah which are obviously closely related to C. cynostigmus and T. marginatum. By examination of these specimens and by morphology-based phylogenetic analysis, it became evident that Cryptopsocus is imbedded within Trichadenotecnum and thus should be synonymized with it. In this paper, we discuss the placement and status of Cryptopsocus and describe three new species which are close to the type species of Cryptopsocus.

For methods, terminologies, and abbreviations used in the paper, see Yoshizawa (2001).

\section{Trichadenotecnum Enderlein}

Trichadenotecnum Enderlein, 1909: 329. Type species Hemerobius sexpunctatus Linnaeus, 1758 (by original designation). 
Cryptopsocus Li, 2002: 1459 (in Chinese); 1899 (in English), n. syn. Type species Cryptopsocus cynostigmus Li, 2002 (by original designation).

See Yoshizawa $(2001,2003)$ and Yoshizawa et al. $(2007,2008)$ for further synonymy and generic definition.

\section{The marginatum group (new species group)}

Diagnosis. Small psocids, forewing length about $2 \mathrm{~mm}$. Forewing broadly but sparsely covered with tiny spots; pterostigma pale except for maculated distal end and posterior tip; opposite spots in cell $\mathrm{r}$ apparent; spot in cell a apparent; basal band running from stigmasac to distal $1 / 3$ of cell cup, with wide transparent area around first segment of $\mathrm{M}$ vein; distal band apparent; spot on roof of cell $\mathrm{m} 3$ distinct; submarginal spots apparent but sometimes indistinct in some cells; marginal cloud almost absent, only recognizable at vein ends; vein Rs forked in right angle; areola postica almost triangular (roof veins slightly angulated); distal vein of areola postica directed posteriorly. Hindwing hyaline. Male terminalia: clunium without lateral processes nor dorsal flap; epiproct lobe weakly to well developed; paraproct with weakly developed basal process; hypandrium asymmetrical, posteromedially with wide membranous region; phallosome symmetrical. Female of this group known only from $T$. tigrinum, described below, therefore variation of female characters among species unknown (see description of female genitalia of this species for a preliminary diagnosis of females of this species group).

Remarks. In the original description of Cryptopsocus, Li (2002) considered the flattened posterior margin of the phallosome to be one of the diagnostic characters of the genus (in Chinese description, p. 1459). In the English diagnosis, it is described as "phallosome acute at base and apex (p. 1900)" but, judging from the illustration (fig. 1304F), the Chinese description seems correct. However, the distal part of the phallosome is highly variable among species of this group and thus this character is unsuitable for group definition. Five species are here assigned to this species group. Based on the hypandrial structures, they can be classified into two subgroups: T. marginatum, $T$. cynostigmus and T. tigrinum by having a movable median tongue and a right corner lacking keels or processes; $T$. sharkeyi and $T$. sabahense by having an unmovable median tongue and a highly modified right corner. The group name is based on T. marginatum, the oldest species name within the group.

\section{Trichadenotecnum marginatum New \& Thornton}

Trichadenotecnum marginatum New \& Thornton, 1976: 413.

Distribution. Malaysia (Peninsula).

Remarks. The only known specimen of this species (male holotype) has not been examined but, judging from the original description, this species is clearly close to T. cynostigmus, the type species of Cryptopsocus treated below, because of the similarity of the hypandrial structures. Diagnostic characters of this species are discussed below (see Remarks to other species of the group).

\section{Trichadenotecnum cynostigmus (Li) n. comb.}

Cryptopsocus cynostigmus Li, 2002: 1459 (in Chinese); 1900 (in English). Note: The species name, based on the Latinized Greek noun "stigmos", is an invariable noun in apposition.

Distribution. China (Hainan Is.).

Remarks. The only known specimen, the male holotype, of this species has not been examined but, judging from the original description and its original generic assignment (see Introduction), this species is clearly a member of the genus Trichadenotecnum because of the apomorphic forewing markings and some venational characters unique to this genus (Yoshizawa, 2001). Diagnostic characters of this species are discussed below (see Remarks to the other species of the group) 
Trichadenotecnum tigrinum n. sp.

(Figs 1A, 2)

Holotype. Male, THAILAND Nakhon Nayok, Khao Yai NP, Nhong ping khaokeaw, 14²3.094N 101²3.055E, 733m, Malaise trap 5-12.iii.2007, Wirat Sukho leg. T2101 (tiger7M, KY436) (will be deposited in the Queen Sirikit Botanical Gardens, Thailand).

Paratypes (will be deposited in the Queen Sirikit Botanical Gardens, Muséum d'histoire naturelle Geneva, and Hokkaido University). [THAILAND] 1 male, Phetchabun, Khao Kho NP, mixed deciduous forest, 16²32.546N 101².501E, 560m, Malaise trap 26.xii.2006-2.i.2007, Somchai Chachumnan \& Saink Singiong leg. T1189; 1 male, Chaiyaphum, Tat Tone NP, by the stream, 1558.771N 102².397E, 305m, Malaise trap 19-26.i.2007, Tawit Jaruphan \& Orawan Budsawong leg. T1564; 2 males, Chaiyaphum, Tat Tone NP, Phu hang sing, 1558.723N $102^{\circ} 2.231 \mathrm{E}, 290 \mathrm{~m}$, Malaise trap 5-12.i.2007, Tawit Jaruphan \& Irwin Budsawong leg. T1560; 1 female, same data as for holotype (tiger7F, KY474); 1 male, same locality as for holotype, 12-19.iii.2007, Wirat Sukho leg. T2104.

Description. Male. Head. White in ground color; vertical markings blackish brown, each marking fused with neighbors; with pair of brown markings anterior to vertical markings next to ocellar field; orbital markings small, brown; coronal suture black; epicranial suture narrowly bordered with blackish brown band dorsally; frons with pair of pale brown markings medially and black small spots laterally; eyes black, IO/D = 1.1; ocelli white, ocellar field dark brown; gena white, medially with blackish brown marking; postclypeus with rows of blackish brown spots, rows fused to each other ventrally, dorsal margin and ventrolateral corners white; anteclypeus blackish brown. Antenna brown. Mouthparts brown.

Thorax. Prothorax brown. Mesonotum mostly brown, medially with white field, marking on anterior lobe bilaterally divided by narrow white stripe. Mesopleuron white, precoxal bridge and trochantin blackish brown. Metanotum brown, medially with white spot, scutellum darker. Metapleuron blackish brown except for white membranous region.

Legs. Coxae blackish brown; femora white, each with black spot ventrally at apical 1/3; tibiae white to pale brown; tarsi brown, second segments darker.

Forewing (Fig. 1A). As in group diagnosis; distal spot in cell a well developed; spot on roof of m3 apparent only in basal half; submarginal spot obscure in cell $\mathrm{m} 3$; roof vein of cell $\mathrm{m} 3$ short, about half of second section of CuA1 in length.

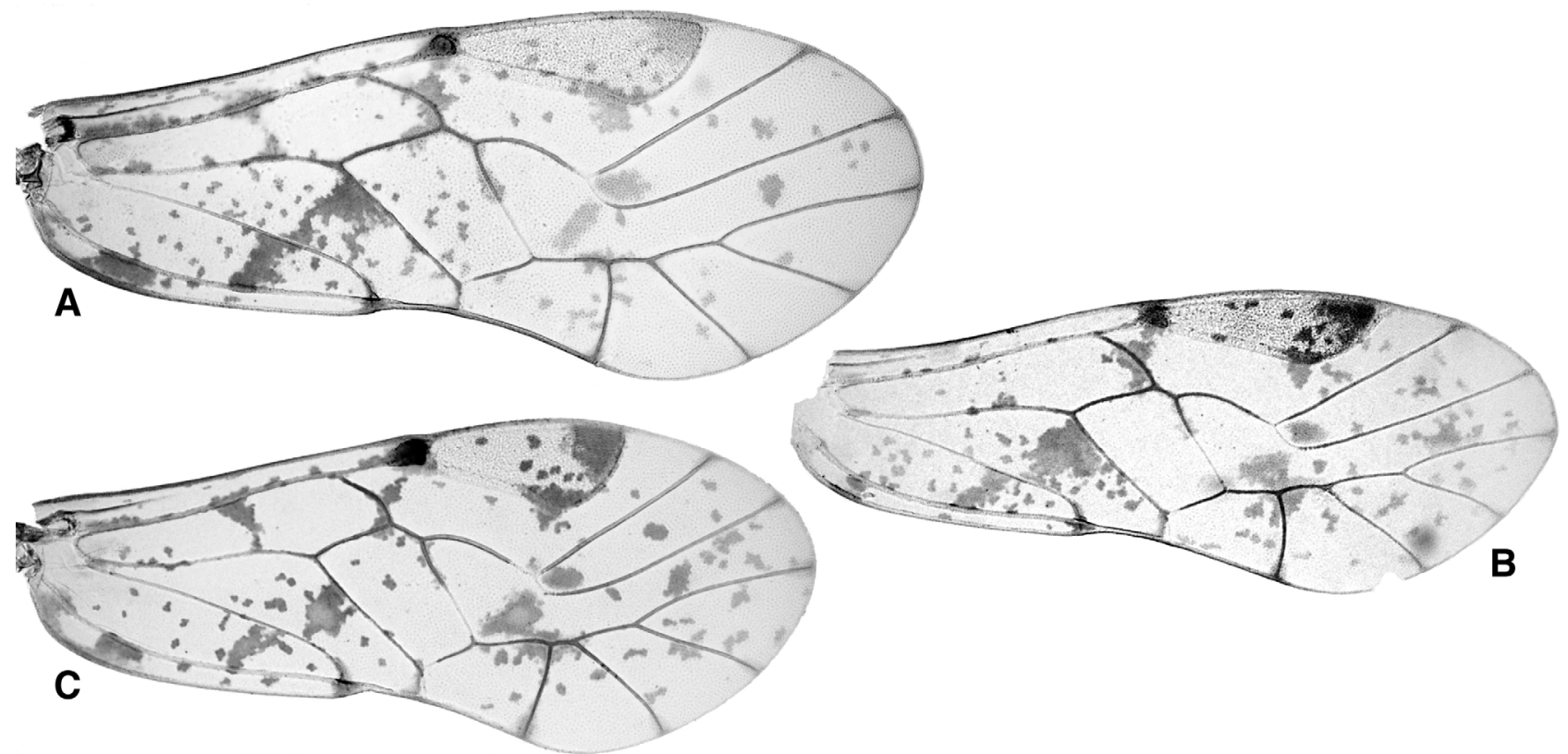

FIGURE 1. Forewings of new species of the Trichadenotecnum marginatum group. A: T. tigrinum, male paratype; B: T. sharkeyi, male holotype; C: T. sabahense, male holotype. 


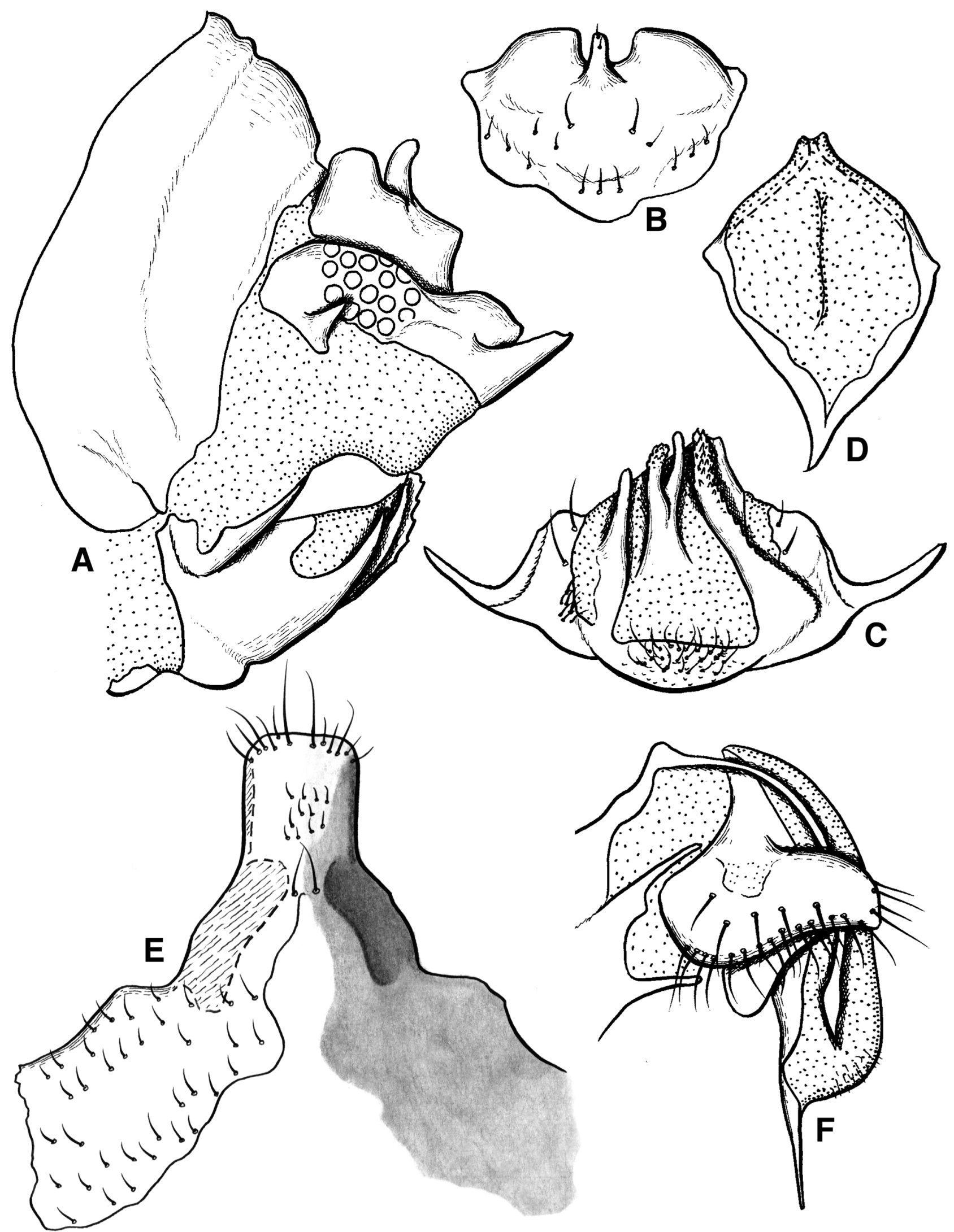

FIGURE 2. Male (A-D) and female (E-F) terminal structures of Trichadenotecnum tigrinum. A: terminalia, lateral view; B: epiproct, posterodorsal view; C: hypandrium, posteroventral view; D: phallosome, ventral view; E: subgenital plate, ventral view; F: gonapophyses, ventral view. 
Terminalia. Eighth sternum with weak sclerite separated from hypandrium (Fig. 2A). Epiproct lobe bilobed, slightly expanded over clunium, medially with cylindrical process strongly pointed dorsally; dorsal margin smooth (Fig. 2AB). Paraproct with small basal conical process; distal process long, almost straight (Fig. 2A). Hypandrium (Fig. 2C) with broad membranous region medially, anteroventral surface weakly projecting ventrally, medially covered with papillae; left corner without significant modification; left process long and straight; median tongue well developed, movable, bifurcated distally, its left lobe covered by denticles, right lobe smooth; right process well developed, covered by denticles distally, outer margin serrated basally; right corner without significant modification. Phallosome (Fig. 2D) pointed anteriorly, posteriorly pointed and narrowly open.

Measurements. Body 1.4-1.7 mm, forewing 2.3-2.4 mm, hindwing 1.7-1.9 mm.

Female. General morphology almost as in male. $\mathrm{IO} / \mathrm{D}=1.2$.

Genitalia. Subgenital plate (Fig. 2E). Egg guide broad basally, gradually narrowing to middle and parallel sided in distal half, distal margin slightly arched, dorsally with lateral sclerites at broadened base; body of subgenital plate with broad membranous region anteriorly, narrowly incising to middle of egg guide. Gonapophyses (Fig. 2F). Ventral valve long; dorsal valve with long and narrow distal process; external valve with well developed posterior lobe, anteriorly with membranous region. Spermapore plate not well sclerotized.

Measurements. Body $1.7 \mathrm{~mm}$, forewing (from base to Rs fork) $1.4 \mathrm{~mm}$ (apically broken), hindwing (from base to R-M fork) $1.0 \mathrm{~mm}$ (distally broken).

Distribution. Thailand.

Etymology. The species epithet refers to the TIGER (Thailand Inventory Group for Entomological Research) project, through which the present material was collected.

Remarks. The hypandrial structure of this species is very similar to T. cynostigmus, but these species differ clearly in the shapes of the epiproct lobe (simple in T. cynostigmus, trilobed in T. tigrinum) and the phallosome (posterior end flattened and closed in T. cynostigmus, pointed and narrowly opened in T. tigrinum). The trilobed structure of the epiproct lobe of this species is similar to T. marginatum (three swellings were shown by New \& Thornton, 1976: fig. 130), but these species differ in the shapes of the phallosome (posterior end wide and straight in T. marginatum, as in T. cynostigmus) and the hypandrium. T. marginatum clearly differs from T. cynostigmus by the characters of the hypandrium. The female of the marginatum species group is described here for the first time.

\section{Trichadenotecnum sharkeyi n. sp.}

(Figs 1B, 3)

Holotype. Male. THAILAND, Nakhon Nayck, Khao Yai NP, entrance of Hong Pak Chee Trail, $14^{\circ} 27.115^{\prime} \mathrm{N}$ 101⒉951E 733m, Malaise trap 19-26.v.2007, Pong Sandao leg. T2270 (tiger8, KY452) (will be deposited in the Queen Sirikit Botanical Gardens, Thailand).

Description (note that the condition of the specimen is bad). Male. Head. White in ground color; vertical markings brown, fused and composing large marking; with pair of faint markings anterior to vertical markings; orbital markings obscure; coronal suture black; epicranial suture dark brown; frons with pair of faint markings; eye black, large, $\mathrm{IO} / \mathrm{D}=0.6$; ocelli white, ocellar field brown; gena white; postclypeus with faint brown markings ventrally; anteclypeus pale brown. Antenna brown (flagellum missing). Mouthparts brown.

Thorax. Prothorax brown. Mesonotum brown, anterior lobe of scutum and scutellum darker; mesopleuron white except for brown precoxal bridge and trochantin. Metanotum brown, anterior lobe of scutum pale; metapleuron brown except for white median region.

Legs. Coxae of all legs brown. Foreleg white, distal part of tibia and tarsus brownish. (Other legs missing.)

Forewing (Fig. 1B). As in group diagnosis; distal spot in cell a obscure; spot on roof of $m 3$ obscure distally, anterointernally broadly connected to posterior spot of distal band; roof vein of cell $\mathrm{m} 3 \mathrm{long}$, about equal to second section of CuA1 in length.

Terminalia. Eighth sternum unsclerotized (Fig. 3A). Epiproct lobe weakly developed, slightly expanded over clunium; dorsal margin covered by papillae, with posterior projection medially (Fig. 3AB). Paraproct with small basal process covered by papillae; distal process broad and short, strongly bent at tip (Fig. 3A). Hypandrium (Fig. 3C) with broad membranous region distal to median tongue, anteroventral surface smoothly curved, with pair of slight swellings; left corner without significant modification; left process short, basally fused with median tongue; 
median tongue small, unmovable, covered by papillae distally, distal margin only slightly concave; right process well developed, internal margin strongly serrated; right corner highly modified, with serrated keel and outer lobes. Phallosome (Fig. 3D) pointed anteriorly, posteriorly closed and slightly bilobed, with papillar region medially.

Measurements. Body $1.7 \mathrm{~mm}$, forewing $2.1 \mathrm{~mm}$, hindwing $1.6 \mathrm{~mm}$.

Female. Unknown.

Distribution. Thailand.

Etymology. The specific epithet is dedicated to Dr Michael Sharkey (University of Kentucky, USA), leader of the TIGER project .

Remarks. This species is clearly differentiated from the above-mentioned three species by the shapes of the epiproct lobe and the hypandrial processes.

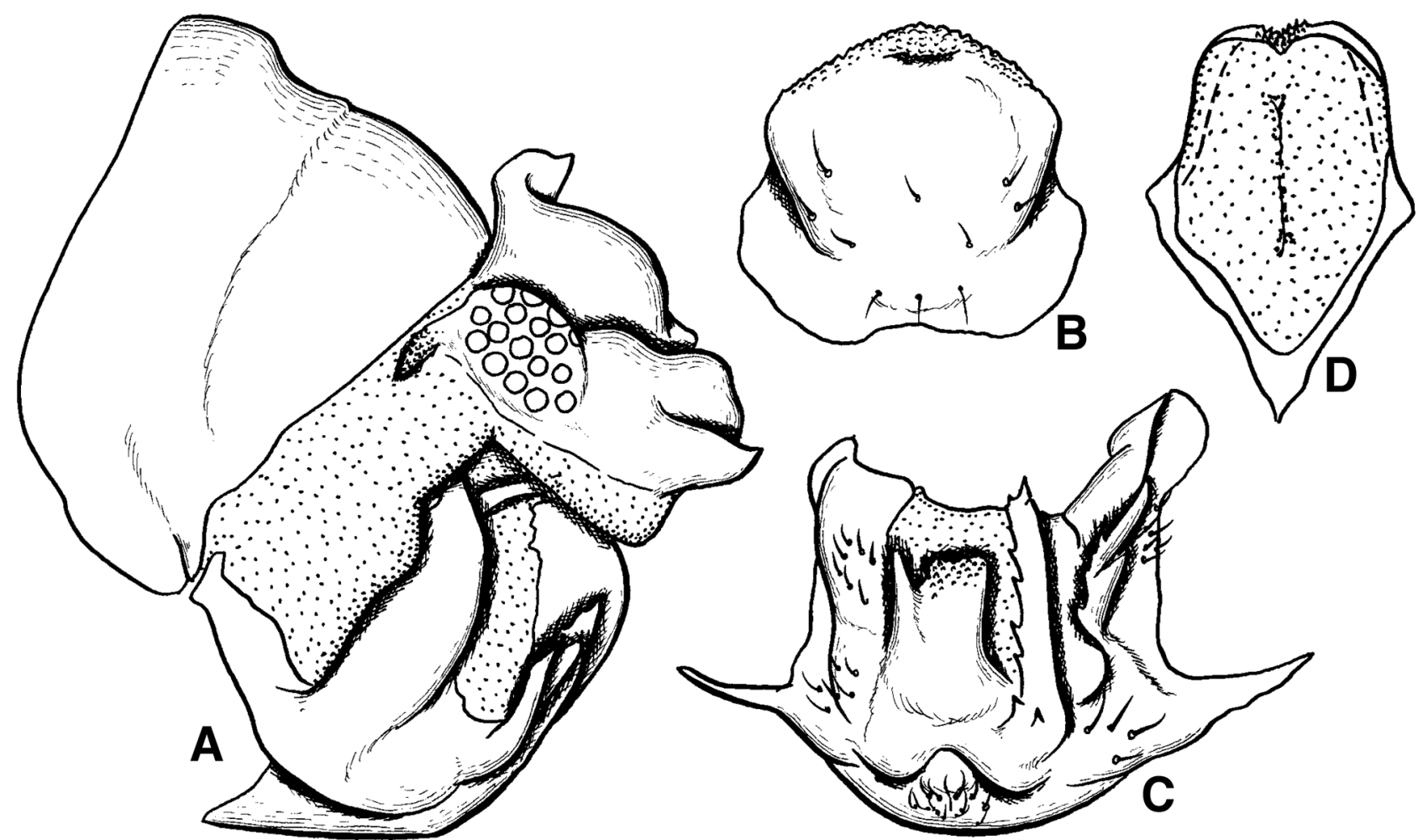

FIGURE 3. Male terminal structures of Trichadenotecnum sharkeyi. A: terminalia, lateral view; B: epiproct, posterodorsal view; C: hypandrium, posteroventral view; D: phallosome, ventral view.

\section{Trichadenotecnum sabahense $\mathbf{n}$. sp.}

(Figs 1C, 4)

Holotype. Male. MALAYSIA: SABAH (Interior Residency): Kimanis road, 16 miles from Keningau, heliport, sifting in cloud forest, 1380 m, 12.v.1982, B.Hauser leg (sabah1, KY461) (will be deposited in the Muséum d'histoire naturelle, Geneva, Switzerland).

Description. Male. Head. Head white in ground color; vertical markings blackish brown, each marking touching with neighbors; with pair of anterior spots anterior to vertical markings; orbital markings obscure; coronal suture blackish; epicranial suture narrowly bordered with brown band dorsally; frons with pair of brown markings medially; gena white; eye black, $\mathrm{IO} / \mathrm{D}=1$; ocelli white, ocellar field brown; postclypeus with brown spots medially; anteclypeus brown. Antenna brown, scape and pedicel darker. Mouthparts brown.

Thorax. Prothorax brown. Mesoscutum with large brown marking on each lobe, marking on anterior lobe darker, scutellum dark brown. Mesopleuron white except for brown precoxal bridge and trochantin. Metascutum mostly brown, medially with pale region; scutellum dark along anterior margin, pale along posterior margin. Metapleuron brown except for white membranous region. 
Legs. Coxae of all legs dark brown. Fore legs brown except for white distal half of femur. Mid and hind legs white except for brown basal end of femur and tarsus.

Forewing (Fig. 1C). As in group diagnosis; distal spot in cell a apparent; spot on roof of $\mathrm{m} 3$ apparent, anterointernally narrowly connected to posterior spot of distal band; roof vein of cell $\mathrm{m} 3$ very short, about $1 / 3$ of second section of $\mathrm{CuA} 1$ in length.

Terminalia. Eighth sternum broadly sclerotized, fused to hypandrium posteromedially (Fig. 4A). Epiproct lobe well developed, strongly expanded dorsally and over clunium; dorsal margin covered by papillae, with posterior projection medially (Fig. 4AB). Paraproct with tiny basal process covered by denticles; distal process narrow and short, strongly curved, with tiny notch at tip (Fig. 4A). Hypandrium (Fig. 4C) with broad membranous region distal to median tongue, anteroventral surface strongly projecting ventrally, with medial swelling covered with papillae; left corner with wrinkled lobe; left process absent; median tongue well developed, unmovable, covered by papillae distally, distal margin only slightly curved; right process well developed, covered by denticles; right corner highly modified, with wrinkled lobe. Phallosome (Fig. 4D) rounded anteriorly, posteriorly closed, bilobed, covered by papillae.

Measurements. Body $1.7 \mathrm{~mm}$, forewing $2.0 \mathrm{~mm}$, hindwing $1.9 \mathrm{~mm}$.

Female. Unknown.

Distribution. Malaysia (Sabah).

Etymology. The specific epithet refers to the region of origin of the holotype.

Remarks. This species is very close to T. sharkeyi, described above, on the basis of the epiproctal and hypandrial structures, but these species differ clearly in many genital structures, including the distal structure of the phallosome (Figs 3D and 4D).

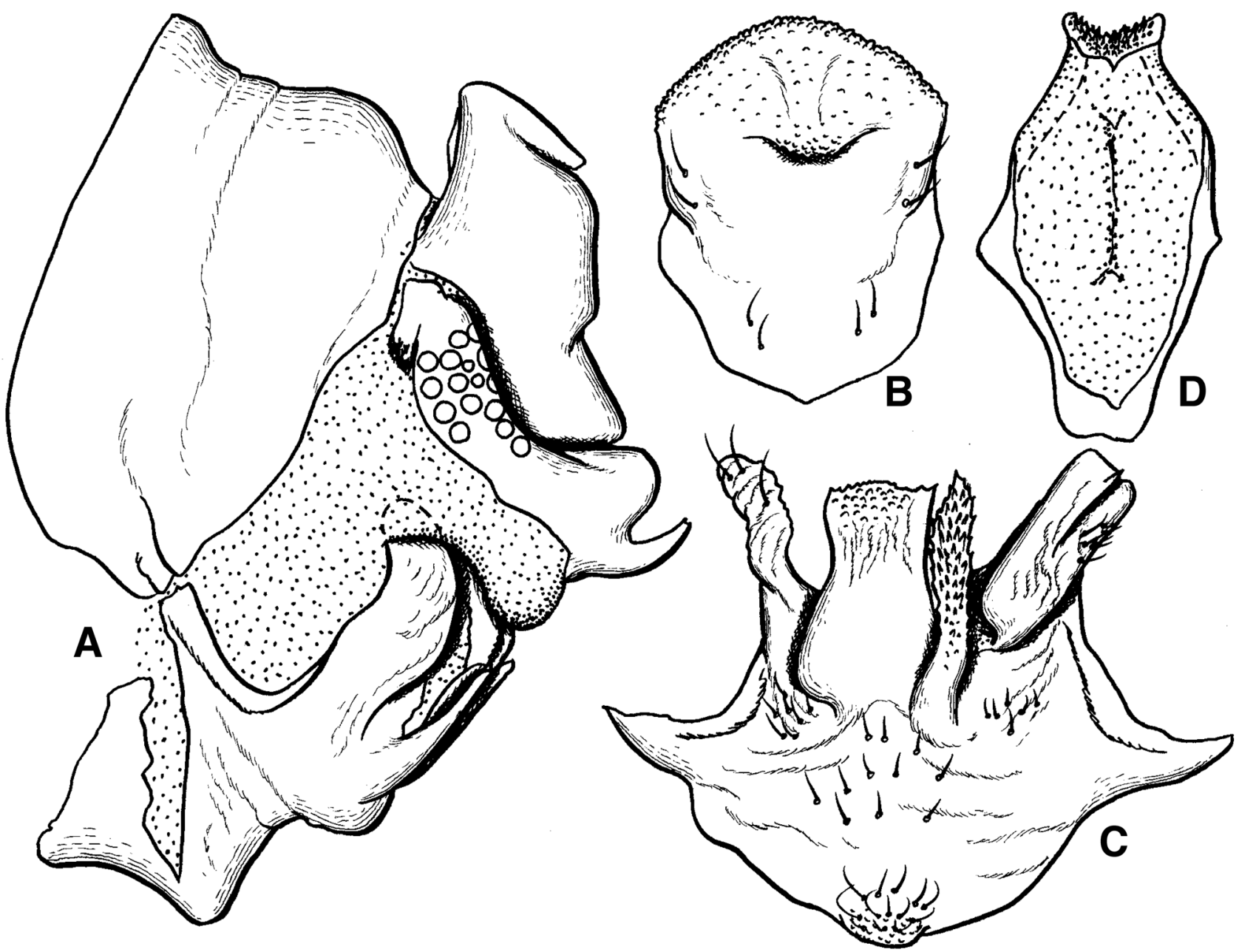

FIGURE 4. Male terminal structures of Trichadenotecnum sabahense. A: terminalia, lateral view; B: epiproct, posterodorsal view; C: hypandrium, posteroventral view; D: phallosome, ventral view. 


\section{Phylogenetic placement}

Phylogenetic placement of the marginatum group (= former genus Cryptopsocus) was tested morphologically. Morphological characters of T. tigrinum, for which both males and females are available, and T. sabahense, known only from males, were scored, and data were appended to the matrix presented in Yoshizawa (2004) and Yoshizawa et al. (2008). Data matrix is available from TreeBase (http://purl.org/phylo/treebase/phylows/study/TB2:S17425) or http://insect3.agr.hokudai.ac.jp/Cryptopsocus.phylog/. Maximum parsimony analysis of the data matrix (see Yoshizawa et al. 2008 for analytical method) yielded 488 equally parsimonious trees (Length $=144$, Consistency Index $=0.403$, Retention Index $=0.742$ ). Application of successive weighting reduced the equally parsimonious trees to seven, which are included in 488 trees estimated by equally weighted analysis. Therefore, the trees estimated from successive weighting of morphological characters were preferred here. Their strict consensus tree is shown in Fig. 5. Placement of the marginatum group within Trichadenotecnum was supported by all 488 trees estimated from equal weighting analysis. Basal relationships within Trichadenotecnum were completely unresolved in the consensus of 488 trees but, after application of successive weighting, basal split of the marginatum group from the rest of Trichadenotecnum excluding the corniculum + roesleri groups (= Neotropical clade: see Yoshizawa et al., 2008) was suggested by all the trees. All species of the marginatum group examined here possess the paraproctal basal process, similar to that observed in the spiniserrulum group. Close relationship

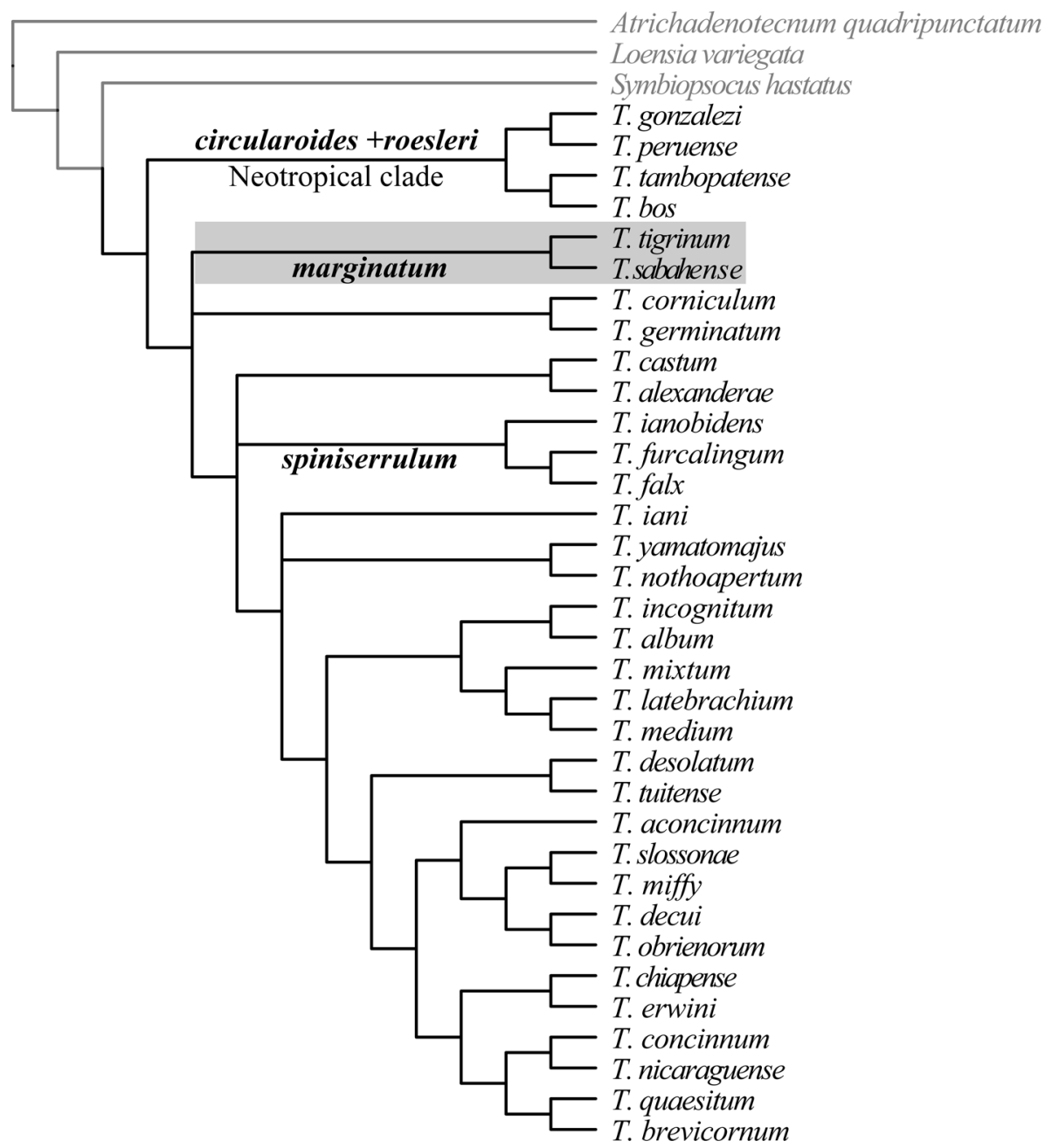

FIGURE 5. Phylogenetic placement of the Trichadenotecnum marginatum group estimated from morphological data. The figure shows strict consensus of seven trees obtained from the successive weighting analysis. Only the species group names mentioned in the discussion are labelled on the branches, and the marginatum group is highlighted by a gray square. 
between the marginatum and spiniserrulum groups was suggested by some of 488 trees but, after application of successive weighting, these groups were placed separately. Ongoing molecular phylogenetic analyses including $T$. tigrinum and T. sabahense support the placement of the marginatum group as estimated from the successive weighting analysis of morphological data (Yoshizawa et al., unpublished data). The presence of the opposite spots in cell $\mathrm{r}$ and vein Rs forked in right or obtuse angle are shared by all Trichadenotecnum species including the marginatum group and excluding the Neotropical clade.

\section{Acknowledgments}

We thank Michael Sharkey for entrusting the psocids collected in the course of the TIGER project to the Geneva Museum of Natural History, and we are grateful to Thérèse Cuche, former technician at the Geneva Museum, for her tireless sorting and labelling of this huge collection which contains most of the material here described. This study was supported by JSPS grant 24570093 to KY.

\section{References}

Enderlein, G. (1909) Neue Gattungen und Arten nordamerikanischer Copeognathen. Bolletino del Laboratorio di Zoologia generale e agraria della R. Scuola Superiore d'Agricoltura in Portici, 3, 329-339.

Li, F-S. (2002) Psocoptera of China. Science Press, Beijing, 1976 pp.

New, T.R. \& Thornton, I.W.B. (1976) Psocomorpha (Psocoptera) from the Malayan Peninsula. Oriental Insects, 9 (December 1975), 375-418. [Note: This paper was published in February 1976 (see footnote on pp. 375)] http://dx.doi.org/10.1080/00305316.1975.10434508

Yoshizawa, K. (2001) Systematic revision of Japanese Trichadenotecnum Enderlein (Psocodea: "Psocoptera": Psocidae: Ptyctini), with redefinition and subdivision of the genus. Invertebrate Taxonomy, 15, 159-204. http://dx.doi.org/10.1071/IT00013

Yoshizawa, K. (2003) Two new species that are likely to represent the most basal clade of the genus Trichadenotecnum (Psocoptera: Psocidae). Entomological Science, 6, 301-308. http://dx.doi.org/10.1046/j.1343-8786.2003.00033.x

Yoshizawa, K. (2004) Molecular phylogeny of major lineages of Trichadenotecnum and a review of diagnostic morphological characters (Psocoptera: Psocidae). Systematic Entomology, 29, 383-394. http://dx.doi.org/10.1111/j.0307-6970.2004.00249.x

Yoshizawa, K. \& Johnson, K.P. (2008) Molecular systematics of the barklouse family Psocidae (Insecta: Psocodea: 'Psocoptera') and implications for morphological and behavioral evolution. Molecular Phylogenetics and Evolution, 46, 547-559. http://dx.doi.org/1o.1016/j.mpev.2007.07.011

Yoshizawa, K., Lienhard, C. \& Thapa, V.K. (2007) Systematic study of the genus Trichadenotecnum in Nepal (Psocodea: 'Psocoptera': Psocidae). Insecta matsumurana, new series, 63, 1-33.

Yoshizawa, K., García Aldrete, A.N. \& Mockford, E.L. (2008) Systematics and biogeography of the New World species of Trichadenotecnum Enderlein (Insecta: Psocodea: 'Psocoptera': Psocidae). Zoological Journal of the Linnean Society, 153, 651-723. http://dx.doi.org/10.1111/j.1096-3642.2008.00398.x

Yoshizawa, K., Lienhard, C. \& Idris, A.B. (2014) Trichadenotecnum species from Peninsular Malaysia and Singapore (Insecta: Psocodea: 'Psocoptera': Psocidae). Zootaxa, 3835 (4), 469-500. http://dx.doi.org/10.11646/zootaxa.3835.4.3 